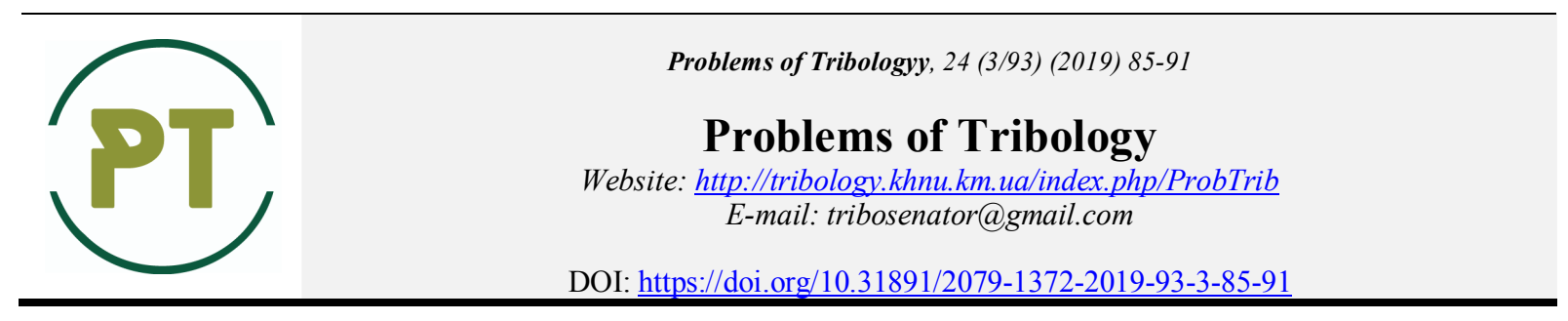

\title{
Features of electrochemical-mechanical running-in of chrome-plated piston rings to the cast-iron surface of the cylinder liner under different friction modes
}

\author{
V. Aulin", T. Zamota, A. Hrynkiv, S. Lysenko, M. Chernovol, A. Chernai \\ Central Ukrainian National Technical University, Kropyvnytskyi, Ukraine \\ *E-mail: AulinVV@gmail.com
}

\begin{abstract}
In this paper, the laws of the electrochemical - mechanical running-in (ECMR) are considered. For elimination of inaccuracies of form of details and errors of assembling mechanism expose to running-in which running- in of the surfaces take place. The most effective factor of acceleration of running-in is to use the combined processes at running- in surfaces. One of them is ECMR..

The results of experimental studies have shown that the the processes of ECMR pass in the environment of electrolyte, which influences efficiency of process, mode of friction at running-in pair and speed of electrochemical reactions. The essence of ECMR consists of the following: working motion for details of mechanism is given, between details an electrolyte is pumping and cutoff alternating current. Due to joint electrochemical-mechanical influence there is a rapid adaptation of one surface to other. The most effective factor of ECMR is electrochemical, at which it is easy to electrochemical stripping of material from the run-in surface due to anodal dissolution at the hydrodynamic lubrication rate.
\end{abstract}

Key words: running-in, electrochemical - mechanical running-in (ECMR), engines, friction mode, piston ring, liner.

\section{Introduction}

Details of units and machines' assemblies are mainly made of high wear resistance materials. It allows to increase their durability by constructive methods, but creates difficulties at carrying out of running-in surfaces. One of the most promising directions in the study of acceleration and improvement of the running-in of the main engine matings is using of combined processes: electrochemical and mechanical. There is a method of electrochemical-mechanical running-in (ECMR) of parts of the main resource-determining matings of machines, using electrochemical and mechanical action, which ensures rapid adaptability of the parts ' surfaces [1-3].

\section{Literature Review}

When running-in of mating parts that have shape deviations, it is necessary to remove part of the material to ensure that the friction surfaces are equidistant $[4,5]$. Since the matings include parts from different materials, it is necessary to create prerequisites for uniform volumetric removal of the material of the parts. According to the researchers [6], during mechanical wear, the least resistance to the volumetric removal rate of the material is provided by aluminum parts.

The most widely used parts of machine matings on the basis of iron, aluminum, copper, nickel and chromium. They form mates in which the wear resistance of parts made of different materials is very different. The wear resistance of such parts is much lower than that of parts made of copper, steel, nickel or chrome plated. In mechanical wear, the wear resistance of chromium is twenty-eight times higher than that of aluminum. In electrochemical etching (ECE), the difference in the resistance to the volumetric removal of the part's material is much lower than in conventional methods of running-in, based on the intensification of mechanical wear of the running-in surfaces: the resistance to the volumetric removal of chromium is seven times higher than that of 
aluminum. Based on this, more preferable are the methods of running-in with ECE of friction surfaces, which ensures uniform running-in of parts from these materials with different wear resistance. as a whole $[6,7]$.

The use of ECMR in running-in of various types of engines confirmed the effectiveness of the method

\section{Purpose}

The aim of the work is to disclosed mechanism of running-in of piston rings to mirror of cylinder, are lacking research outputs on current under various regimes friction in paired ring-thimbles. Needs further investigation is the question of the choice of the electrolyte composition. Taking into account the existing differences in the quality of the chrome coating of piston rings, it is necessary to develop a way to improve the initial state of the ring surfaces before the ECMR.

\section{Research Methodology}

The object of the study is the process of running-in the side surface of the piston ring to the cylinder liner during electrochemical-mechanical running-in.

In the study of the process of running-in friction pairs chrome-cast iron were used real piston rings in conjunction with the pad, cut from the cylinder liner, or with the sleeve itself. The study of the features of the HMP process was carried out on the friction machine SMC-2.

In the ring-pad scheme, a standard mandrel was used to secure the pad. Isolation of the pad from the mass of the friction machine SMC-2 was carried out with the help of a textolite sleeve pressed into the bore hole of this mandrel. The current was supplied to the roller through the mass, and to the pad-through the mandrel.Research in the ring-pad scheme was carried out with the help of special mandrels that allow fixing piston rings on the SMC-2 shafts and supplying current to them (Fig. 1).

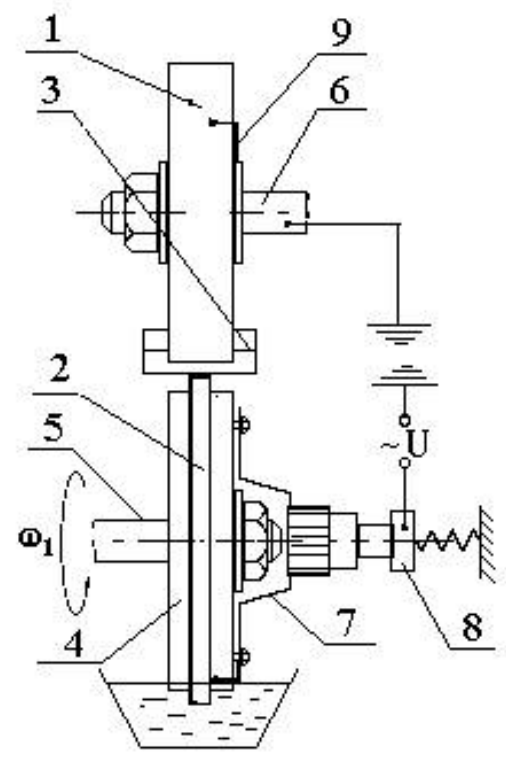

Fig. 1. Supply current in the circuit - pad on the ring:

$$
\begin{gathered}
\text { 1 - upper mandrel; } \\
\text { 2- lower ring; } \\
\text { 3- pad; } \\
\text { 4- lower mandrel; } \\
5 \text { - lower shaft SMC-2; } \\
\text { 6- upper shaft SMC-2; } \\
7 \text { - lower current supply; } \\
\text { 8- copper graphite brush; } \\
\text { 9- upper current supply }
\end{gathered}
$$

Previously, the ring was installed in the caliber of the nominal diameter. A support washer was inserted into the compressed ring, the diameter of the protrusion of which was equal to the inner diameter of the ring.

The rings in the mandrel were fixed by compressing the washer and the support washer with tie bolts with nuts. Then the mandrel with the ring was removed from the gauge and installed on the friction machine shaft. The radial runout of the ring was controlled by an indicator head with an accuracy of $0,01 \mathrm{~mm}$. the current Supply to the rotating rings was carried out according to the scheme presented in Fig. 2.

A spring-loaded copper graphite brush 8 was used to supply current to the lower ring 2 . The upper ring 1 was closed through the mass of SMC-2. 
The current in the circuit was regulated by a laboratory transformer. Current parameters were controlled: voltage - device Щ4313, current - ammeters Д - 566, class - 0.2; Э514, class -0.5.

Studies of conditional current outputs were carried out using copper coulometers according to the generally accepted method $[9,10]$. However, work on alternating current required the setting of two diodes $Д_{1}$ and $Д_{2}$, which separated the currents of positive and negative half-periods.

The calculation was carried out according [11] to the following formula:

$$
B T(\eta)=\frac{m_{m e} \cdot g_{c u}}{g_{m e} \cdot m_{c u}} \cdot 100 \%
$$

where $m_{m e}$ - the mass of the metal released at the cathode, g;

$g_{m e}=\frac{E_{m e}}{F}-$ electrochemical equivalent of the deposited metal, $\mathrm{g} / \mathrm{A} \cdot \mathrm{h}$;

$E_{m e}$ - equivalent weight of metal;

$F$ - Faraday number $(F=26,8 \mathrm{~A} \cdot \mathrm{h} / \mathrm{g})$;

$g_{c u}=\frac{E_{c u}}{F}-$ electrochemical equivalent of copper, $\mathrm{g} / \mathrm{A} \cdot \mathrm{h}$.

The amount of electricity which is passed in $A \cdot h$ was determined by the formula:

$$
q=\frac{m_{c u}}{g_{c u}}=I \cdot \tau
$$

where $I$ - amperage, A;

$\tau$ - duration of electrolysis, h;

$m_{c u}$ - the mass of copper released at the cathode of a copper coulometer, $\mathrm{g}$.

The following electrochemical equivalents of metals were used in the calculations: copper (divalent) $g_{c u 2}=1,186 \mathrm{~g} / \mathrm{A} \cdot \mathrm{h}$; chromium (trivalent) $g_{C r 3}=0,647 \mathrm{~g} / \mathrm{A} \cdot \mathrm{h}$; iron (divalent) $g_{F e 2}=1,0416 \mathrm{~g} / \mathrm{A} \cdot \mathrm{h}$.

All studies were conducted in electrolytes, which are a mixture of glycerol and an aqueous solution of salt. In water solutions were used high purity sodium chloride, analytical grade sodium atomistically and analytical grade sodium nitrate.

The concentration of salts was expressed in mass percentages. Preparation of electrolytes was carried out by the method [2].

The main electrolytes studied were:

1) a mixture of glycerol with $20 \%$ aqueous $\mathrm{NaCl}$ solution in the ratio of four volume parts of glycerol and one volume part of sodium chloride solution;

2) a mixture of glycerol with $20 \%$ aqueous solution of $\mathrm{NaNO}_{2}$ in the ratio of four volume parts of glycerol and one volume part of sodium nitrite solution;

3) a mixture of glycerol with $20 \%$ aqueous solution of $\mathrm{NaNO}_{3}$ in the ratio of four volume parts of glycerol and one volume part of sodium nitrate solution.

Preparation of one liter of electrolyte 1, 2 or 3 was carried out as follows. In $40 \mathrm{~g}$ of salt, distilled water was added to the total volume of $200 \mathrm{ml} .800 \mathrm{ml}$ of glycerin was added to the solution and the mixture was thoroughly mixed.

\section{Results}

As a result of the carried out researches dependences of wear and outputs on a current for chrome and cast iron, changes of voltage of an idle course and working at changing density of a current in various electrolytes were received.

In general, it is possible to note the low efficiency of ECMR in the conditions of the boundary mode of friction of the worked surfaces. Lubrication conditions significantly influenced the course of the ECMR process in the friction pair chrome surface of the ring-cast iron pad. Wear of chromium and cast iron remained low (up to $0,5 \mathrm{mg}$ ) and did not depend on the current density up to $14000 \mathrm{~A} / \mathrm{m}^{2}$. Over $14000 \mathrm{~A} / \mathrm{m}^{2}$, there is some increase in wear of chromium when working in the medium of electrolytes containing nitrite or sodium nitrate. And in the electrolyte with sodium nitrate wear is higher. The current outputs of chromium and cast iron at current densities above $4000 \mathrm{~A} / \mathrm{m}^{2}$ do not exceed $3 \%$ at lower current densities, the current output increases, reaching $30 \%$ for an electrolyte with sodium nitrate, but this increase can be attributed to mechanical removal of the material. 
Therefore, in these studies, it is probably possible to talk about the conditional current output at the boundary and alternation of the boundary and hydrodynamic modes of friction. It is obvious that under these conditions, the features of electrolytes are weak and the main current passes through the areas of direct contact. Thus, to obtain a certain current density on all electrolytes, it was required to set the idling voltages close in value, and the values of the operating voltages were practically the same.

With the transition to the gap - contact mode, the electrochemical factor ECMR was amplified. To compare the results of wear chrome ring and cast iron cylinder liner (pads) were conducted experiments without current, that is, at a density $\mathrm{D}$ equal to zero.

With increasing current density, starting from 0 , wear increased. The greatest wear of the friction pair parts - up to $9.8 \mathrm{mg}$ - was achieved with a guaranteed gap between the surfaces (hydrodynamic lubrication conditions).

The study of the metal current output showed that their greatest values occurred at hydrodynamic friction, which indicates an increase in the electrochemical component in this type of lubricant: the maximum value $\eta$ at the boundary friction was $28 \%$, at mixed - boundary and hydrodynamic - $57 \%$ and at hydrodynamic $98 \%$.

In real conditions of friction of a ring at ECMR when there are types of greasing from boundary to hydrodynamic, it is necessary to aspire to increase of a share of the last.

The nature of the salts that make up the electrolytes influenced the performance of electrochemical running-in. Studies at constant load $\left(0.37 \mathrm{MPa}\right.$ ) and varying voltage $U_{x x}$ (from 1,4 to $6,4 \mathrm{~V}$ ) in various electrolytes and without electrolyte showed the following. The resistance in contact depends on the type of electrolyte.

The electrolyte with $\mathrm{NaCl}(1)$ is characterized as the most active, it activates the surface, lowering the transition resistance. The largest voltage drop was obtained on a pair with $\mathrm{NaNO}_{3}$ (3) electrolyte $(100-130 \mathrm{mV})$. The intermediate largest voltage drop in the contact was occupied by an electrolyte containing $\mathrm{NaNO}_{2}(2)$ $(40-110 \mathrm{mV})$.

As the current density increased, wear increased (Fig. 2, a, b), and in the conditions of alternating boundary and hydrodynamic modes of friction, the features of electrolytes are manifested and it is possible to conduct their comparative analysis from the standpoint of wear, current outputs and changes in current parameters. If we consider that the ring is constantly in contact with the sleeve in real conditions of running-in, and the surface of the sleeves contacts at a particular point periodically, then the electrolyte should provide the greatest removal of chromium and the least cast iron. In the current density range up to $6000 \mathrm{~A} / \mathrm{m}^{2}$, this condition corresponds to the electrolyte with $\mathrm{NaNO}_{3}$ (Fig. 2, a), the wear of chromium in it reaches 1,5 mg, and cast iron does not exceed $0,6 \mathrm{mg}$.

In other electrolytes, chromium wear is lower and cast iron wear is higher. With an increase in the current density over $6000 \mathrm{~A} / \mathrm{m}^{2}$, an increase in the wear of the friction pair materials in the electrolyte with $\mathrm{NaNO}_{2}$ was observed, which even led to a certain increase in the conditional current outputs at $7000 \ldots 8000 \mathrm{~A} / \mathrm{m}^{2}$ in this electrolyte. This phenomenon can be associated with the appearance of intense gas formation, which was observed when using an electrolyte with $\mathrm{NaNO}_{2}$ starting with an idle voltage $U_{x x}$ equal to $3 \mathrm{~V}$. From Fig. 2. b is clearly visible from the knee of the curve Up for a given voltage. The increase in wear due to erosion processes is undesirable, and the same increase in wear of cast iron and chromium does not meet the above requirements for the electrolyte.

At current densities $\mathrm{D}$ greater than $6000 \mathrm{~A} / \mathrm{m}^{2}$ in electrolytes $\mathrm{C} \mathrm{NaCl}$ and $\mathrm{NaNO}_{3}$ there was a monotonic increase in wear. In relation to cast iron, the electrolyte based on sodium nitrate was more active, starting from $7000 \mathrm{~A} / \mathrm{m}^{2}$. Most likely, this is due to changes in the friction conditions in the pair. When the no-load voltage reaches $4 \mathrm{~V}$, the operating voltage has an extremum and then decreases slightly. This is also due to gas formation in the electrolyte with $\mathrm{NaNO}_{3}$, but the process proceeded stably and did not go into the area of catastrophic wear. The characteristic bending of the operating voltage at $U_{x x}$ equal to $4 \mathrm{~V}$ had an electrolyte with $\mathrm{NaCl}$.

The value of the electrochemical factor, in full, can be estimated by the results of the addition of steam, chrome-cast iron in the hydrodynamic mode of friction. Current outputs exceeded those obtained in other modes. Sharply increased the consumption of materials, and, as can be seen from Fig. 2, b and 2, b, b the chromium removal is directly proportional to the no-load voltage required to create a certain current density. In general, the presence of an electrolyte layer separating the surface increased the transient resistance of the contact, which led to the use of high voltage.

Under clearance conditions, a faster increase in chrome wear (Fig. 2, c) was observed in electrolytes with $\mathrm{NaNO}_{2}$ and $\mathrm{NaNO}_{3}$, but the least wear of cast iron occurs in the electrolyte based on $\mathrm{NaNO}_{3}$. In all experiments, gas formation was observed, which reduced the carrying capacity of the electrolyte layer, but the use of the upper headstock of the friction machine kept the gap constant. It is obvious that at a voltage above $4 \mathrm{~V}$ at the gap there is an intensive anodic dissolution of chromium and cast iron. For running-in mode, when the surfaces are separated by a layer of electrolyte, is the most preferable [2]. 

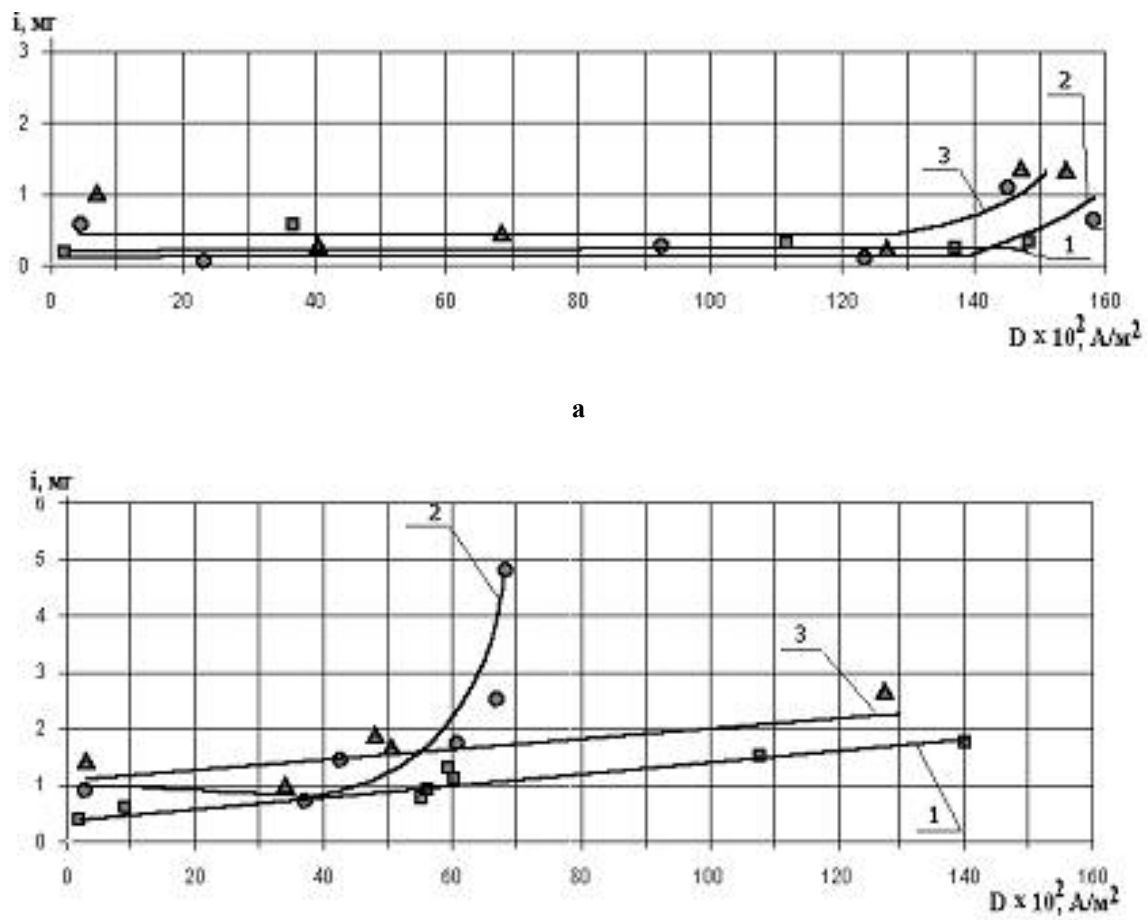

b

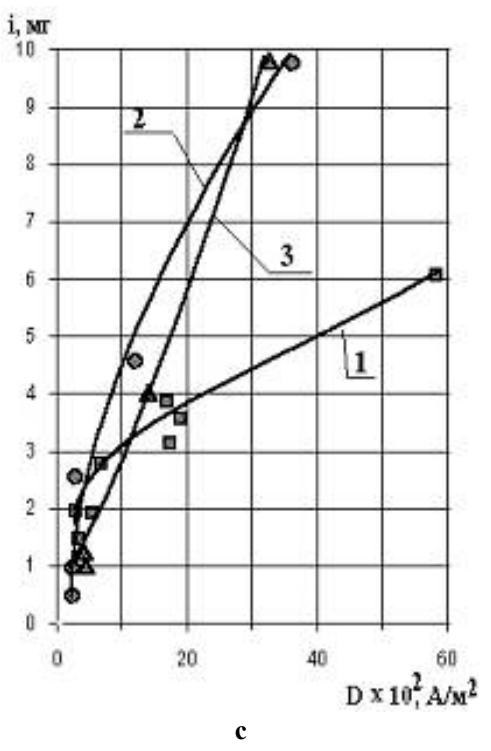

Fig. 2. Chrome plating wear: a-boundary friction;

b - alternation of boundary and hydrodynamic friction; c-hydrodynamic mode of friction;

1 - electrolyte consisting of a mixture of $20 \%$ aqueous solution of $\mathrm{NaCl}$ and glycerol, in a ratio of $1 / 4$;

2 - electrolyte consisting of a mixture of $20 \%$ aqueous solution of $\mathrm{NaNO}_{2}$ and glycerol, in a ratio of $1 / 4$;

3 - electrolyte consisting of a mixture of $20 \%$ aqueous solution of $\mathrm{NaNO}_{3}$ and glycerol, in a ratio of $1 / 4$

Experiments on the friction pair-chrome surface of the ring-cast iron pad-showed that the use of electrolyte with $\mathrm{NaCl}$ led to increased chromium etching, the formation of deep porosity. The electrolyte containing $\mathrm{NaNO}_{3}$ provided a smooth surface of chromium, and the electrolyte with $\mathrm{NaNO}_{2}$ had a weak effect on the change in surface roughness. The highest chromium removal (up to $2 \mathrm{mg}$ ) and the lowest cast iron (up to $0,5 \mathrm{mg}$ ) were achieved by using an electrolyte with $\mathrm{NaNO}_{3}$, which took place at current densities up to $6000 \mathrm{~A} / \mathrm{m}^{2}$.

Thus, for the running-in of the chrome surface of the ring and the cast-iron sleeve, an electrolyte containing sodium nitrate is preferred. 


\section{Summary}

1. In real conditions, the addition of a pair of friction chromium-cast iron must be carried out with the alternation of boundary and hydrodynamic modes of friction. At the same time, it is necessary to strive to increase the share of the hydrodynamic friction regime.

2. For carrying out electrochemical-mechanical addition (finishing) of coupling the chrome ring-mirror of a sleeve of cylinders the electrolyte of the following composition is preferable: $20 \%$ aqueous solution of sodium nitrate with addition of glycerol in the ratio $1 / 4$.

3. The change in microgeometry is influenced by electrical parameters and the mode of loading of friction pairs; in our experiments, the best results were obtained at an idle voltage $U_{x x}$ equal to $4 \mathrm{~V}$.

\section{References}

1. Alekseev V. P. Electrochemical-mechanical macro-running-in of parts /V. P. Alekseev. // Monograph-Lugansk: Elton-2, 2011. - 204p. (Russian)

2. Zamota T. N. Control of the processes of running-in of the main conjugations of machine parts in the manufacture and repair: Monograph. / T. N. Zamota, V. V. Aulin. - Kirovograd: Publisher Lysenko V. F.-2015. 304 p. (Russian)

3. Aulin, V., Hrynkiv, A., Lysenko, S., Rohovskii, I., Chernovol, M., Lyashuk, O., Zamota, T. Studying truck transmission oils using the method of thermaloxidative stability during vehicle operation / EasternEuropean Journal of Enterprise Technologies, 1 (6-97), pp. 6-12. (English)

4. Aulin, V., Derkach, O., Makarenko, D., Hrynkiv, A., Pankov, A., Tykhyi, A. Analysis of tribological efficiency of movable junctions "polymeric-composite materials - steel" / Eastern-European Journal of Enterprise Technologies, 4 (12-100), pp. 6-15. (English)

5. Aulin, V., Hrynkiv, A., Lysenko, S., Dykha, A., Zamota, T., Dzyura, V. Exploring a possibility to control the stressed-strained state of cylinder liners in diesel engines by the tribotechnology of alignment / Eastern-European Journal of Enterprise Technologies, 3 (12-99), pp. 6-16. (English)

6. Kuzmenko A. G. Studies of non-contact interaction of lubricated friction surfaces: Monograph. / A. G. Kuzmenko, O. V. Dikha. // - Khmelnitsky: KhNU, 2005. - 183 p. (Russian)

7. Zamota T.N. Electrochemical basis of the process macrorunning-in of flat friction surfaces at ECMR(G). / T.N. Zamota. // Problems of tribology. International scientific journal. - Khmelnitsky National University. - 2011. - №4.- P.56-61. (Russian)

8. Aulin, V., Hrinkiv, A., Dykha, A., Chernovol, M., Lyashuk, O., Lysenko, S. Substantiation of diagnostic parameters for determining the technical condition of transmission assemblies in trucks / EasternEuropean Journal of Enterprise Technologies, 2 (1-92), pp. 4-13. (English)

9. Zamota T.N. Comparative evaluation of the effectiveness of different methods of ECMR(G) in the running-in of sliding bearings. / T.N. Zamota , R.V. Zorin. - Problems of tribology. International scientific journal. - Khmelnitsky National University.- 2009. - №4. - P.58-62. (Russian)

10. Aulin V.V. The effectiveness of the method of ECMR to eliminate various macrogeometric deviations mates parts at production and repair / V.V. Aulin, T.N. Zamota, M.I.Chernovol // Bulletin of the engineering Academy of Ukraine. - 2015. - №4. - P. 168-174. (English)

11. Moroz I.I. Fundamentals of improving the accuracy of electrochemical shaping. / I. I. Moroz. Chisinau: Stiinta, 1977.- 293p. (Russian) 
Аулін В.В., Замота Т.М., Гриньків А.В., Лисенко С.В., Черновол М.І., Чернай А.Е. Особливості електрохіміко-механічного припрацювання хромованих поршневих кілець до чавунної поверхні гільзи циліндру при різних режимах тертя.

Виконаний аналіз літературних джерел показав, що для усунення неточностей форми деталей i помилок складання механізм піддають обкатці, при якій відбуваються припрацювання поверхонь. Найбільш ефективним фактором прискорення обкатки $€$ використання комбінованих процесів на поверхнях деталей, що припрацьовуються. Одним 3 таких процесів - єлектрохіміко-механічне припрацювання.

Результати експериментальних досліджень показали, що процеси ЕХМП протікають в середовищі електроліту, що впливає на ефективність процесу, режим тертя при обкатці пари і швидкість протікання електрохімічних реакцій. Сутність ЕХМП полягає в наступному: приводяться в робочий рух деталі механізму, між деталями прокачують електроліт і пропускається змінний струм. Завдяки спільному електрохіміко-механічному впливу відбувається швидка адаптація однієї поверхні до іншої. Найбільш ефективним фактором ЕХМП є електрохімічний, при якому легко відбувається електрохімічне вилучення матеріалу 3 поверхні деталі при припрацюванні за рахунок анодного розчинення при гідродинамічному режимі тертя.

Значення електрохімічного фактору, повною мірою, можна оцінити за результатами припрацювання пари, хром-чавун при гідродинамічному режимі тертя. Виходи по струму перевищували отримані при інших режимах. Різко збільшене знімання матеріалів для хрому прямо пропорційне напрузі холостого ходу, необхідному для створення певної щільності струму. Взагалі, наявність розділення поверхонь деталей шаром електроліту підвищило перехідний опір контакту, що обумовило використання великої електричної напруги. При наявності зазору між деталями спостерігається більш швидке зростання зносу хрому в електролітах з $\mathrm{NaNO}_{2}$ i $\mathrm{NaNO}_{3}$. В той час найменший знос чавуну відбувається в електроліті на основі $\mathrm{NaNO}_{3}$. У всіх дослідах було наявне газоутворення, що знижувало несучу здатність шару електроліту, але використання підпору верхній бабки машини тертя витримувало зазор постійним. Очевидно, що при напрузі вище 4В на зазорі відбувається інтенсивне анодне розчинення хрому і чавуну. Для припрацювання режим, коли поверхні розділені шаром електроліту, є найкращим.

Ключові слова: припрацювання, електрохіміко-механічне припрацювання (ЕХМП), двигун, режим тертя, поршневе кільце, гільза. 